\title{
Enkephalin Biosynthesis and Enkephalin Gene Expression Are Increased in Hippocampal Mossy Fibers Following a Unilateral Lesion of the Hilus
}

\author{
Jeffrey D. White, Christine M. Gall, ${ }^{1}$ and Jeffrey F. McKelvy \\ Department of Neurobiology and Behavior, SUNY, Stony Brook, New York 11794, and 'Department of Anatomy, \\ University of California, Irvine, California 92717
}

The biosynthesis and posttranslational processing of proenkephalin and the level of preproenkephalin mRNA were investigated in the mossy fiber system of the granule cells of the hippocampus in the presence or absence of a unilateral lesion of the hilus, a procedure that produces an episode of recurrent bilateral hippocampal seizures lasting several hours. Both immunocytochemistry and radioimmunoassay (RIA) have demonstrated that the hilus lesion leads to large bilateral increases in enkephalin immunoreactivity in the mossy fiber system. In the present study, RIA data indicate that following an initial decline in immunoreactivity, enkephalin content within the mossy fibers first begins to increase between 18 and $24 \mathrm{hr}$ after lesioning. Using the technique of in vivo radiolabeling and high-performance liquid chromatographic purification of identified radiolabeled peptides, we observed a 14-fold increase in incorporation of radiolabeled methionine into $\mathrm{Met}^{5}$-enkephalin at 24-30 hr postlesion, as compared with control animals, when Mets- $^{5}$ enkephalin was purified from the mossy fiber terminal fields. To examine the posttranslational proteolytic processing of proenkephalin, the biosynthesis of 5 additional Met5-enkephalin-containing peptides was also examined. We determined that the posttranslational processing of proenkephalin did not yield exclusively penta-, hepta-, and octapeptides but larger opioid peptides as well in both control and lesioned animals, and that the ratio of the enkephalin peptides was not altered following the lesion. Measurement of preproenkephalin messenger RNA levels in the granule cells by Northern analysis revealed a marked increase following the lesion. Compared with the control animals, preproenkephalin mRNA was 8.5 -fold higher in the contralateral dentate gyrus at $12 \mathrm{hr}$ postlesion and 14- to 15-fold higher by $24 \mathrm{hr}$. These data support the hypothesis that recurrent seizure activity stimulates a large increase in enkephalin biosynthesis in the dentate gyrus granule cells.

Two families of opioid peptides, the dynorphins and the enkephalins, have both been demonstrated to be localized within the mossy fiber axons of the hippocampal dentate gyrus granule

\footnotetext{
Received Mar. 11, 1986; revised June 24, 1986; accepted Aug. 28, 1986.

We thank Drs. K. Yoshikawa and S. Sabol for the rat preproenkephalin cDNA clone pRPE2. This work was supported by NIH Grant NS 20372 and NSF Grant BNS 8111475 to J.F.M., and NSF Grant BNS 8417098 and Research Career Development Award NS00915 to C.M.G.

Correspondence should be addressed to Jeffrey $\mathrm{D}$. White, $\mathrm{Ph} . \mathrm{D}$., Division of Endocrinology, Health Sciences Center, T-15-060, SUNY Stony Brook, Stony Brook, NY 11794.

Copyright @1987 Society for Neuroscience 0270-6474/87/030753-07\$02.00/0
}

cells (Gall et al., 1981b; McGinty et al., 1983). It has recently been demonstrated that a number of seizure-producing treatments -including repeated electroconvulsive shock (Hong et al., 1985b), intraventricular kainic acid (Hong et al., 1980), electrolytic lesion to the dentate gyrus hilus (Gall et al., 1981a, 1986), and amygdaloid kindling (Hong et al., 1985a)-either increase hippocampal enkephalin content as measured by radioimmunoassay (RIA) or increase the intensity of enkephalin immunostaining localized within the mossy fibers. The observation of increased mossy fiber enkephalin content following seizure is interesting for a number of reasons. First, it may pertain to the regulation of seizure activity or seizure susceptibility in the hippocampus. Hippocampal region CA3, the area in which the mossy fibers terminate, is one of the most seizure-susceptible regions of the forebrain (Malamud, 1966; Schwartzkroin and Prince, 1978), and the peptide enkephalin, the content of which increases in this area after seizure, has known epileptogenic effects when applied to hippocampus (Elazar et al., 1979). Second, perturbations in the balance of mossy fiber opioid peptides might provide an opportunity to identify the contribution of these substances to synaptic physiology in this system. Finally, and most pertinent to the present report, the influence of seizure activity on mossy fiber enkephalin content may represent a dramatic example of the regulation of the biosynthesis of a neuroactive substance by physiological activity.

The present studies were initiated in order to better understand the mechanism by which enkephalin levels increase in the mossy fibers following seizure. Specifically, we have examined whether enkephalin synthesis in the granule cell/mossy fiber system is altered following the placement of a small unilateral lesion within the hilus of the dentate gyrus. Electrophysiological recordings from hippocampal region CA3 of alert, chronically implanted rats and mice have demonstrated that this lesion initiates an episode of bilateral recurrent electrographic seizure activity lasting for approximately $10-12 \mathrm{hr}$ postlesion (Gall et al., 1986). We now report that the increase in enkephalin immunoreactivity seen following this treatment is due to an increase in enkephalin biosynthesis in the mossy fiber system, which is preceded by an increase in preproenkephalin mRNA. Our results suggest that this response of hippocampal enkephalinergic neurons represents an extremely useful system for further studies of the relationship between neuronal activity and neuropeptide gene expression.

\section{Materials and Methods}

Materials. Male Sprague-Dawley rats (200-250 gm) were used for these studies. Peptide standards were from Bachem. Reverse-phase $\mathrm{C}_{18}$ high- 
performance liquid chromatography (HPLC) columns were from Vydac. The HPLC system was either a Hewlett-Packard model 1084B or 1090A. ${ }^{35} \mathrm{~S}$-methionine, ${ }^{125} \mathrm{I}$-enkephalin, and GeneScreen Plus were from New England Nuclear. Model 2001 osmotic minipumps were from Alza Corp. $[\alpha]^{32}$ P-CTP was from Amersham.

Immunohistochemistry. Coronal sections through the hippocampus were processed for immunohistochemistry as described elsewhere (Gall et al., 1981b).

Radioimmunoassay. The anti-Met-enkephalin antibody MET 102 was a gift of Drs. I. B. Black and E. F. LaGamma. This antibody recognizes Met $^{5}$-enkephalin, Met $^{5}$-sulfoxide enkephalin with $64 \%$ cross-reactivity and Leu ${ }^{5}$-enkephalin with $5 \%$ cross-reactivity; it does not significantly cross-react with MERGL, MERF, $\beta$-endorphin, substance $P$, or somatostatin. Half-maximal displacement is at $12-20 \mathrm{pg} /$ tube. The assay procedure was as described elsewhere (LaGamma et al., 1984). Trypsin/ carboxypeptidase B treatment of samples for RIA was performed by incubating samples in $0.5 \mu \mathrm{g}$ trypsin (Worthington) in $0.1 \mathrm{M}$ ammonium bicarbonate, $\mathrm{pH} 7.8$, for $60 \mathrm{~min}$ at $37^{\circ} \mathrm{C}$. Phenylmethylsufonyl fiuoride was added to $1 \mathrm{~mm}$ and sodium chloride was added to $0.1 \mathrm{M}$. Carboxypeptidase B (Sigma), 0.1 units, was added, and the samples were incubated at room temperature for $10 \mathrm{~min}$. HPLC analysis showed that these conditions yielded complete conversion of MERGL to MENK.

Protein determination. Protein contents were determined by the method of Lowry et al. (1951).

Surgical procedures and label administration. Enkephalin biosynthesis was evaluated using the cannulation/isotope infusion protocol described elsewhere (McKelvy et al., 1983; White et al., 1984). Experimental animals were anesthetized with ether, and a lesion was placed in the hilus of the right dentate gyrus (A $-3.8 \mathrm{~mm}, \mathrm{~L} 2.5 \mathrm{~mm}, \mathrm{~V} 3.0$ $\mathrm{mm}$ from bregma) using an insulated stainless steel wire and anodal current of $0.8 \mathrm{~mA}$ for $8 \mathrm{sec}$. Control (sham-lesion) animals were similarly anesthetized and an electrode was briefly lowered into the cortex overlying the right hippocampus but no lesion was made. At the time of lesioning or sham-lesioning, a cannula was implanted into the left dentate gyrus (A - $3.8 \mathrm{~mm}, \mathrm{~L} 2.5 \mathrm{~mm}, \mathrm{~V} 2.8 \mathrm{~mm}$ from bregma). Infusion of radiolabel $\left(500 \mu \mathrm{Ci}^{35} \mathrm{~S}\right.$-methionine; specific activity, $\left.>1000 \mathrm{Ci} / \mathrm{mmol}\right)$ began $24 \mathrm{hr}$ later using an osmotic minipump delivery system (McKelvey et al., 1983; White et al., 1984).

Hilus lesions for Northern blot analysis were placed as above but with animals under ketamine/xylazine anesthesia (10 mg xylazine, 50 $\mathrm{mg}$ ketamine $/ \mathrm{kg}$ ). Control animals were anesthetized, but no surgery was performed. Animals were observed for $5 \mathrm{hr}$ postlesion and behavioral seizures rated using the scale of Racine (1972).

Tissue harvest and peptide purification. The animals were killed by decapitation $6 \mathrm{hr}$ after initiation of label infusion. The cannulated hippocampus, contralateral to the lesion, was dissected free and longitudinally subdivided into $\mathrm{CA} 3$ (containing the mossy fibers) and $\mathrm{CA} 1$ / dentate gyrus (containing granule cell bodies) samples. The tissue was homogenized in the buffer of Bennett et al. (1982) at $4^{\circ} \mathrm{C}$ in the presence of $25 \mu \mathrm{g}$ of each carrier peptide.

The initial HPLC purification was a 3-step linear gradient of $0.1 \mathrm{M}$ phosphoric acid-0.1 M monobasic sodium phosphate $(\mathrm{pH} 2.3)$ and acetonitrile. Following conversion of the enkephalin peptides to the methionine sulfoxide form, the second HPLC step was an exponential gradient of triethylammonium phosphate (McKelvey et al., 1983) and acetonitrile. Following lyophilization, Met $^{3}$-enkephalin (MENK), $\mathrm{Met}^{5} \mathrm{Arg}^{6} \mathrm{Gly}^{7} \mathrm{Leu}^{8}$-enkephalin (MERGL) and $\mathrm{Met}^{5} \mathrm{Arg}^{6} \mathrm{Phe}^{7}$-enkephalin (MERF) were converted to the sulfone form by incubation with $50 \%$ performic acid on ice for $30 \mathrm{~min}$; BAM $18 \mathrm{P}$ was not treated further. The final HPLC system was an exponential gradient of $0.1 \%$ trifluoroacetic acid and acetonitrile. Additional details of the chromatographic conditions are given elsewhere (White and McKelvey, 1986). Recoveries of the added carrier peptides through the final HPLC step were $(\% \pm$ SD): MENK, $53 \pm 10$; MERGL, $47 \pm 6$; MERF, $48 \pm 11$; BAM, 18 P $38 \pm 17$

Nucleic acid techniques. Total nucleic acid was extracted from phenolchloroform extracts of the region of the granule cells, as described elsewhere (White et al., 1986b). Total RNA was prepared from these samples by treatment with RQ1 DNase (Promega Biotech), phenol/chloroform extraction, and ethanol precipitation.

Identical concentrations of denatured RNA from normal and lesioned animals were applied to $1 \%$ agarose- $6 \%$ formaldehyde gels. Following electrophoresis, nucleic acid was transferred to Gene-Screen Plus in $10 \times$ SSC overnight $(1 \times \mathrm{SSC}=0.15 \mathrm{M} \mathrm{NaCl}, 0.015 \mathrm{~m}$ sodium citrate). Prehybridization was carried out according to the manufacturer's instructions.
For hybridization probe, we used a ${ }^{32} \mathrm{P}$-labeled RNA probe generated by subcloning the 911 -base-pair Sac I-Sma I fragment of the rat preproenkephalin clone pRPE2 (18) into pSP64 (Promega Biotech) and then transcribing the RNA probe from the SP6 promoter according to the manufacturer's suggestions. The probe, $2 \times 10^{7} \mathrm{cpm}$, was allowed to hybridize overnight at $65^{\circ} \mathrm{C}$ with constant agitation. Blots were washed in a final solution of $0.1 \times \mathrm{SSC}-1.0 \%$ SDS at $65^{\circ} \mathrm{C}$ for $30 \mathrm{~min}$ with constant agitation. Preflashed film was exposed with an intensifying screen for $2-20 \mathrm{hr}$ at $-80^{\circ} \mathrm{C}$. Quantitation of autoradiographic bands was accomplished using a Joyce-Loebl Ephortec scanning densitometer using the raster scan mode to yield density values of the entire electrophoretic band. All scans were made with exposures in the linear range of the film and of the densitometer.

\section{Results}

\section{Enkephalin content in the mossy fibers}

Figure 1 illustrates the appearance of the hilus lesion used in the present study, as well as the influence of such a lesion on enkephalin-like immunoreactivity in the mossy fiber system innervating region $\mathrm{CA} 3$ of the contralateral hippocampus. This lesion generally ablated the hilus, regions of stratum granulosum, and part of region $\mathrm{CA} 3 \mathrm{c}$; this lesion also severs a narrow span of the strictly ipsilateral mossy fiber axonal system. As described elsewhere (Gall et al., 1981a), and illustrated in Figure $1, C$ and $D$, such a lesion results in a dramatic bilateral increase in enkephalin immunoreactivity localized to all intact mossy fibers. There is also a more modest increase in immunoreactivity within the lateral entorhinal cortex (perforant path) afferents to the dentate gyrus molecular layer (not shown). Immunocytochemical preparations have further indicated there is an initial decline in mossy fiber immunoreactivity in the first $12 \mathrm{hr}$ postlesion and a return to normal by $24 \mathrm{hr}$, followed by the elevation to supranormal levels, as illustrated. In order to quantify this change, as well as to identify an appropriate interval for the analysis of enkephalin peptide biosynthesis, enkephalin was extracted from dissected CA3 regions of whole hippocampus at $12,18,24$, and $30 \mathrm{hr}$ postlesion and 12,18 , and $30 \mathrm{hr}$ postsham lesion. Enkephalin immunoreactivity within the extracts was detcrmincd by a spccific Mct $^{5}$-cnkcphalin radioimmunoassay (Table 1). In this and subsequent analyses the hippocampus contralateral to the experimental treatment was evaluated. A slight decrease in the content of MENK immunoreactivity was detected in the lesioned animals at 12 and $18 \mathrm{hr}$ after the lesion, but by $24 \mathrm{hr}$ postlesion the content reached $116 \%$ of control values and by $30 \mathrm{hr}$ increased further to $155 \%$ of control values. The possibility that the increased immunohistochemical staining in part reflected an increase in the relative amounts of larger MENK-containing peptides was tested by treating the $30 \mathrm{hr}$ postlesion and control sample with trypsin and carboxypeptidase $B$ to release all MENK from larger peptides. For tissue from both control and lesioned animals, the amount of MENK immunoreactivity in the untreated samples was $52 \%$ of the total amount of MENK in the enzyme-treated samples.

\section{Enkephalin biosynthesis}

To determine whether the increase in the MENK content of the hippocampal mossy fibers was due to increased biosynthesis of MENK, we used our previously described techniques for examining enkephalin biosynthesis in vivo (White and McKelvy, 1986). In the present studies we also examined the proteolytic posttranslational processing of the enkephalin precursor by studying the biosynthesis of 5 additional Met $^{5}$-enkephalin-containing peptides. Thus, $24 \mathrm{hr}$ after the hilus lesion or a sham 
Table 1. Enkephalin content in mossy fibers

\begin{tabular}{ll} 
Sample & $\begin{array}{l}\text { Enkephalin } \\
(\mathrm{pg} / \mathrm{mg} \text { protein })\end{array}$ \\
\hline Control & \\
$12 \mathrm{hr}$ & 3859 \\
$18 \mathrm{hr}$ & 1957 \\
$30 \mathrm{hr}$ & 4402 \\
Implanted & 3480 \\
Mean & $3417 \pm 483$ \\
Lesion & \\
$12 \mathrm{hr}$ & $2614 \pm 537$ \\
$18 \mathrm{hr}$ & $3769 \pm 522$ \\
$24 \mathrm{hr}$ & $3973 \pm 275$ \\
$30 \mathrm{hr}$ & $5292 \pm 816^{a}$ \\
\hline
\end{tabular}

Values are the means of immunoreactive Met-enkephalin harvested from the mossy fibers (region CA3) from control and hilus-lesioned animals at the times indicated following either the lesion or the sham lesion. $n=2$ for each control time point, and $n=3$ for each lesion time point. The mean protein recovered in the $\mathrm{CA} 3$ region was $0.44 \mathrm{mg}( \pm 0.12)$.

${ }^{-}$Different from the mean control values at $p<0.025$ ( $t$ test)

lesion, $500 \mu \mathrm{Ci}$ of ${ }^{35} \mathrm{~S}$-methionine was infused above the contralateral hilus over a period of $4 \mathrm{hr}$; this was followed by a 2 $\mathrm{hr}$ infusion of artificial extracellular fluid to allow sufficient time for peptide processing and axonal transport. Hippocampal region CA3, ipsilateral to the infusion, was dissected and the radiolabeled enkephalin peptides were purified to constant radiochemical specific activity using sequential HPLC purification and chemical modification. Figure 2, $A-D$, illustrates that radiolabeled MENK, MERGL, MERF, and BAM 18P were all purified from the mossy fiber terminal field. As the figure demonstrates, approximately twice as much MERF was harvested from the terminals as MERGL, although they each occur once in the proenkephalin precursor (Yoshikawa et al., 1984), and roughly equimolar amounts of MERGL and BAM $18 \mathrm{P}$ were found in the mossy fibers. (BAM 18P contains 2 methionine residues.) In a subset of experiments we also investigated the synthesis of metorphamide (Weber et al., 1983) and peptide E (Kilpatrick et al., 1981) and found that neither was present in greater than $10 \%$ of the molar amount of MERF. When this type of analysis was repeated on several control and lesioned animals, we observed an approximately 14 -fold greater incorporation of radiolabel into the enkephalin peptides in the lesioned animals compared to the control animals. However, the ratio of the 4 enkephalin peptides did not change as a consequence of the lesion (Table 2). Note that an animal that received a cannula implantation but no lesion did not show an increase in enkephalin immunoreactivity, suggesting that the cannulation protocol itself did not mimic the effect of the hilus lesion (Table 1). Determination of total protein specific activity from the granule cell and mossy fiber samples showed that there was no increase in total protein specific activity following the lesion and that the total radioactivity recovered in enkephalin represented approximately $0.01 \%$ of the total protein radioactivity in both lesioned and control animals (not shown).

Figure 1. Photomicrographs illustrating $(A)$ the hilus lesion used in the present study as seen in a Nissl-stained coronal section through the rostral hippocampus and $(B-D)$ the appearance of peroxidase-antiperoxidase labeled enkephalin-like immunoreactivity within the mossy fiber $(m f)$ afferents to the stratum lucidum $(s l)$, region CA3 of $(B)$ an
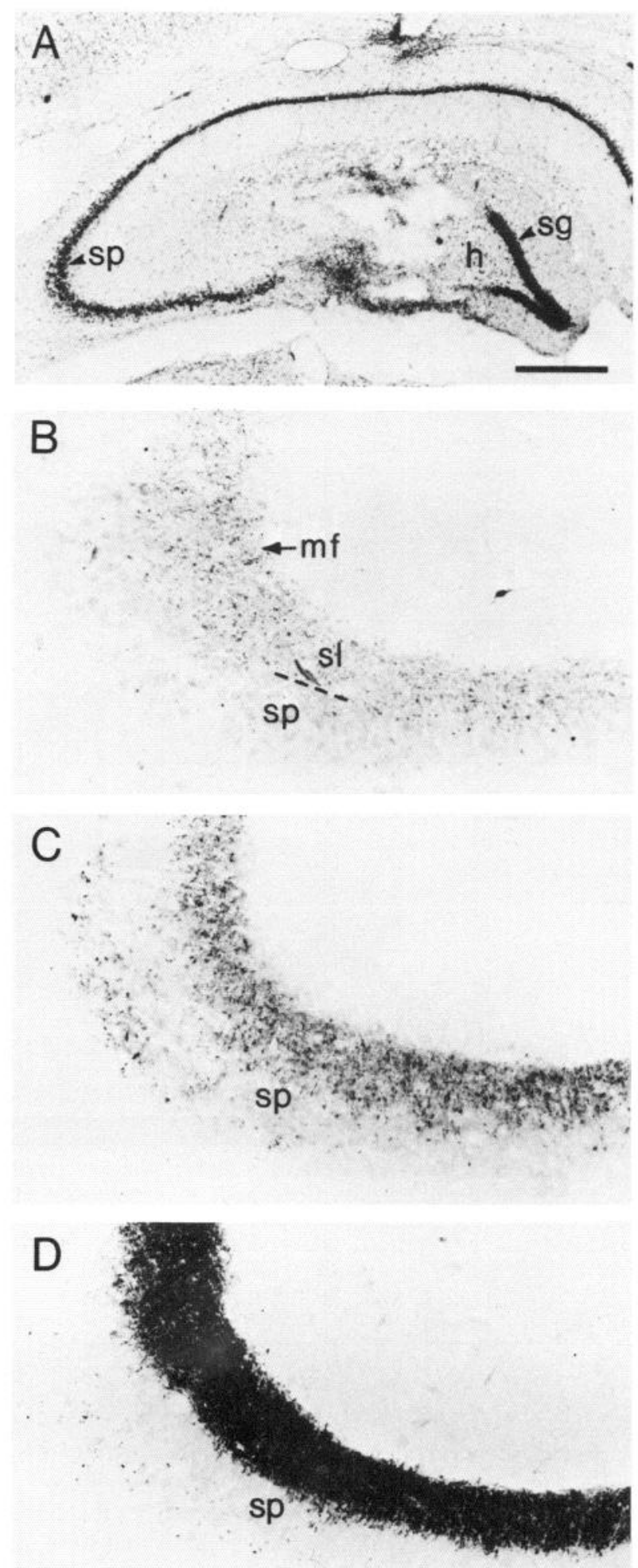

untreated rat and paired experimental animals sacrificed $28 \mathrm{hr}(C)$ and $96 \mathrm{hr}(D)$ after a contralateral hilus lesion. Note that the lesion $(A)$ typically ablates the majority of the dentate gyrus hilus $(h)$, lateral stratum granulosum $(s g)$, and portions of stratum pyramidale $(s p)$, region $\mathrm{CA} 3 \mathrm{~b}$. Following such a unilateral lesion, enkephalin immunoreactivity is depleted from stratum lucidum by $12 \mathrm{hr}$ postlesion (not shown), increases to supranormal levels by $28 \mathrm{hr}(C)$, and appears to reach a maximum by $72-96 \mathrm{hr}(D)$. These changes in enkephalin immunoreactivity are evident throughout all intact mossy fibers, bilaterally. Calibration bar: $A, 500 \mu \mathrm{m} ; B-D, 100 \mu \mathrm{m}$. 

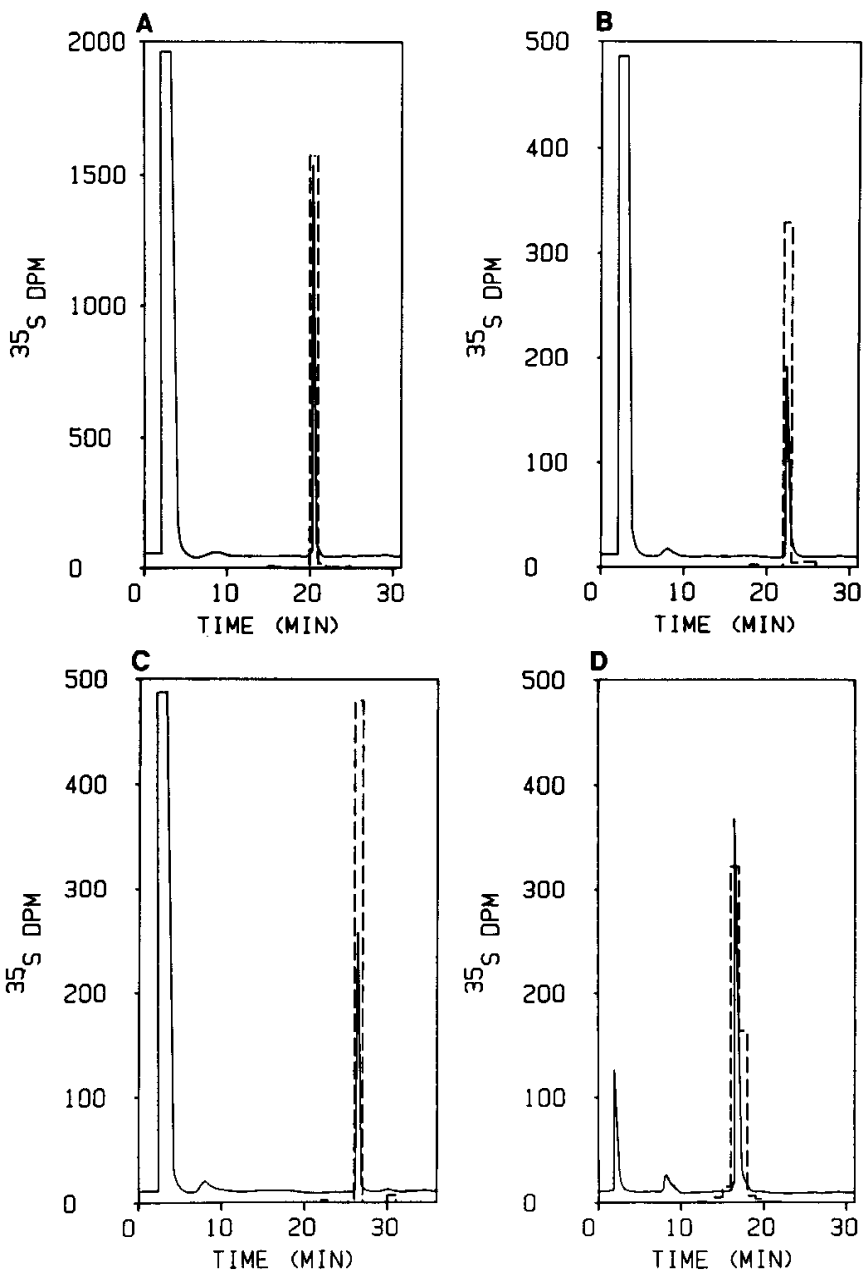

Figure 2. ${ }^{35}$ S-radioactivity, shown as the open histograms (dashed line), and UV absorbance profiles, measured at $210 \mathrm{~nm}$ and shown as the continuous trace, for each of the enkephalin peptides for the final HPLC purification step. MENK $(A)$, MERGL $(B)$, and MERF $(C)$ are the methionine-sulfone forms of the peptide. BAM 18P $(D)$ is the sulfoxide form. The radioactivity plotted for each peptide has been corrected for the recovery of the initially added carrier peptide, to permit comparison of the radioactivity isolated in each peptide. Note that in all cases a single peak of radioactivity exactly comigrated with the added standard peptide.

\section{Preproenkephalin $m R N A$ measurement}

We next tested the hypothesis that the increase in enkephalin biosynthesis following the hilus lesion was accompanied by an increase in the content of mRNA coding for preproenkephalin in the granule cells. Total RNA was extracted from the dentate gyrus samples collected from the same animals that were used for determination of $\mathrm{CA} 3$ enkephalin peptide content (Table 1). The RNA isolated from these samples was subjected to Northern blot analysis for the determination of preproenkephalin mRNA content after denaturing agarose gel electrophoresis. The data from this analysis are shown in Figure 3. The preproenkephalin mRNA content was very low in all control samples. In contrasi, a dramatic increase in the single species of RNA hybridizing to the ${ }^{32} \mathrm{P}$-labeled RNA probe was detected as early as $12 \mathrm{hr}$ after lesioning (8.5-fold above control), this increase in preproenkephalin mRNA rising to 14 - to 15 -fold by $24 \mathrm{hr}$.
Table 2. Enkephalin biosynthesis and processing in hippocampal mossy fibers

\begin{tabular}{lll} 
Sample & $\begin{array}{l}\text { MENK } \\
(\mathrm{dpm})\end{array}$ & $\begin{array}{l}\text { MENK: MERGL: } \\
\text { MERF : BAM 18P }\end{array}$ \\
\hline Control & $209 \pm 79$ & $3.4: 0.6: 1: 0.7$ \\
Hilus lesion & $3078 \pm 1450$ & $3.2: 0.5: 1: 0.6$
\end{tabular}

Mean radioactivity recovered in Met ${ }^{5}$-enkephalin from the mossy fibers from control and hilus-lesioned animals, corrected for the recovery of the initially added carrier peptide ( $\perp$ SEM). For the lesioned animals, 8 animals were analyzed ( 4 for BAM 18P); for control animals, 6 animals were analyzed for MENK (dpm), 4 for MERGL and MERF, and 2 for BAM 18P. The control animals are different from the lesioned animals, with respect to incorporation, at $p=0.001$ by Mann-Whitney $U$ test.

\section{Discussion}

Immunohistochemical studies have demonstrated a large bilateral increase in enkephalin immunoreactivity in the hippocampal mossy fibers following the placement of a small, seizureproducing electrolytic lesion in the dentate gyrus hilus. The present study has demonstrated by 3 independent criteria that enkephalin biosynthesis in the mossy fiber system increases following this treatment: (1) Radioimmunoassay of enkephalin content in the mossy fiber region increased $55 \%$ above control values by $30 \mathrm{hr}$ postlesion; (2) incorporation of radiolabeled methionine into enkephalin harvested from the mossy fibers increased 14-fold by 24-30 hr postlesion; and (3) preproenkephalin mRNA content rose 14-fold in the granule cell region 24 $\mathrm{hr}$ following the lesion. These data support the notion that enkephalin biosynthesis is stimulated by the increased neuronal activity in the form of recurrent seizures. Indeed, this hypothesis is strengthened by the observation that the animal that displayed a relatively smaller increase in preproenkephalin mRNA (L24 $i$ and c, Fig. 3) also displayed more modest behavioral seizure activity.

The posttranslational proteolytic processing of proenkephalin in the mossy fiber system, as indicated by the ratio of radioactivity present in the 4 enkephalin-containing peptides, does not appear to be altered as a consequence of the lesion. The finding that trypsin-carboxypeptidase B treatment of mossy fiber extracts led to an approximate 2-fold increase in enkephalin pentapeptide immunoreactivity in both control and hilus-lesioned animals, as measured by RIA, suggests that in experimental animals there was not an accumulation of large, unprocessed enkephalin-containing peptides. Therefore, the 4 enkephalin-containing peptides on which we concentrated comprise the major enkephalin-containing species in this projection system and can account for $83 \%$ of the radioactivity predicted to be in enkephalin. The remaining radioactivity is likely to be contained in metorphamide and peptide $\mathrm{E}$, as we observed a small amount of incorporation into these 2 peptides, and other proenkephalin processing intermediates. Although it is possible that the enzyme conditions used here were sufficient to release pentapeptide from some extended forms of Met-enkephalin but not from the prohormone, and thus some increase in prohormone occurred in the mossy fibers following the lesion, we do not feel that this possibility is likely as there was close agreement of the data between normal and hilus-lesioned animals. Moreover, the present data are in agreement with the data of Beaumont et al. (1985), who demonstrated the presence of only small amounts of proenkephalin precursor peptides in striatal tissue. 


\section{SC12 C 18 C 30 L 12 L 18 L 24 L 30 i c i c 1218 S}

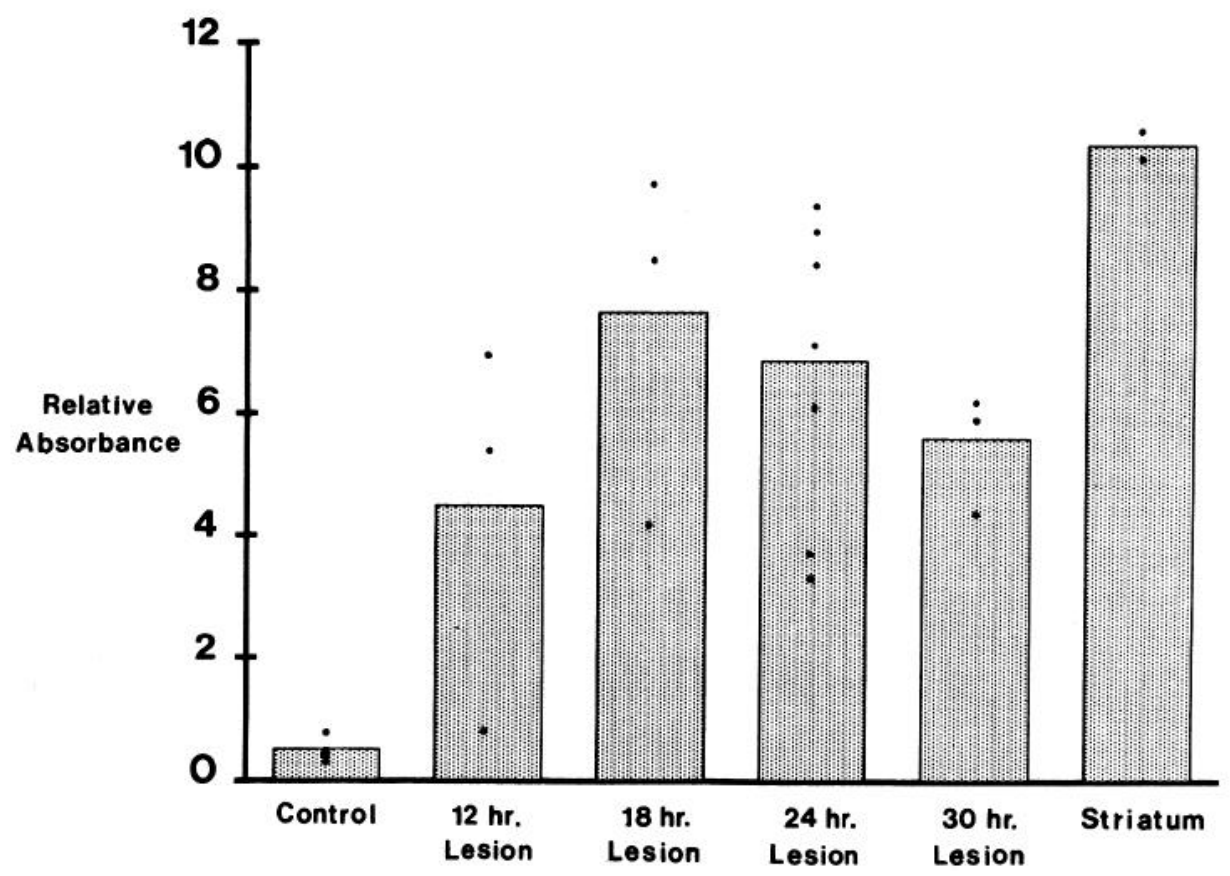

Figure 3. Upper panel, Autoradiogram of the Northern blot analysis for the presence of prepoenkephalin mRNA in samples of RNA isolated from control and hilus-lesioned animals. All lanes received $10 \mu \mathrm{g}$ RNA. The numbers above the lanes represent the time (in hr) after operation. Except where indicated, all samples were taken from the hippocampus contralateral to the lesion or sham-lesion. $C$, Control; $L$, hilus lesion; $i$, ipsilateral to hilus lesion; $c$, contralateral to hilus lesion; $S, 10 \mu \mathrm{g}$ RNA isolated from rat striatal tissue (to serve as a positive control). The 2 groups of control and lesioned animals were from separate experiments. Densitometric values for the control lanes were obtained with a 10 -fold longer exposure (not shown). The single RNA species detected by the ${ }^{32} \mathrm{P}-\mathrm{RNA}$ probe is indicated by the arrow. Lower panel, Histograms of the mean densitometric values obtained from the samples shown above. The filled circles represent the actual values obtained. When no value for a control sample could be obtained, the sample was excluded from the analysis; hence, the derived stimulation values represent the minimum amount of stimulation observed. 
The finding that the posttranslational processing of proenkephalin appeared to remain constant following the lesion lends further support to our previous evidence for the specificity of proenkephalin processing within neuronal systems. That is, within a specific projection system the relative amounts of the Met-enkephalin peptides present are constant; however, these relative ratios differ between different projection systems (White et al., 1986a). The present data also imply that the mechanisms through which proenkephalin undergoes posttranslational processing are unchanged following the hilus lesion. Thus, the enzymes responsible for these processing events, primarily proteolytic enzymes, must either be present in sufficient amounts to meet the increased demand of elevated peptide biosynthesis or the synthesis of these enzymes is regulated in parallel with the synthesis of proenkephalin.

The difference in the magnitude of the increase in enkephalin biosynthesis between the RIA data and the protein biosynthetic and mRNA data is striking. This may reflect increased rates of enkephalin release following seizures, as suggested by the decline in enkephalin content at early postlesion intervals. Thus, the steady-state mossy fiber enkephalin content may rise only slightly by $30 \mathrm{hr}$ postlesion, as the increased rate of enkephalin synthesis is paralleled by increases in the rate of transmitter release. We are currently investigating the dynamics of enkephalin biosynthesis and release in the mossy fibers following seizure activity to address the general problem of the regulation of neuropeptide metabolism.

We should emphasize that the hilus-lesion paradigm employed in the present study yields bilateral, electrophysiologically identified episodes of epileptiform activity in hippocampus with full paroxysmal discharges that recur for approximately 12 hr postlesion (Gall et al., 1986). This bilateral effect following the unilateral lesion appears to depend upon both the integrity of the hippocampal commissural pathway and neuronal activity, i.e., severing the commissural projections or maintenance of animals under pentobarbital anesthesia inhibits both the bilateral radiation of seizure activity and increases in enkephalin immunostaining (Gall et al., 198 la). The activation of enkephalin biosynthesis in this paradigm thus appears attributable to increased neuronal activity associated with seizure and offers a promising system for the further analysis of the regulation of enkephalin biosynthesis in the CNS. Given the defined anatomy and physiology of the mossy fiber system, and the availability of a paradigm for the rapid and dramatic stimulation of enkephalin biosynthesis, it will now be possible to evaluate the relative contribution of such processes as increased neuronal firing, peptide release, and specific receptor activation on the regulation of enkephalin biosynthesis by the granule cells. Interestingly, the increase in enkephalin biosynthesis that is apparently the result of increased neuronal activity during seizures, both in the present study and in other CNS systems following repeated electroconvulsive shock (Yoshikawa et al., 1985), is in contradistinction to the inhibition of enkephalin biosynthesis observed when cultured rat adrenal medullae are depolarized (LaGamma et al., 1985). These disparate findings leave open the possibility that enkephalin gene expression can be under either positive or negative control depending upon either the particular postsynaptic receptors present on an enkephalin-synthesizing cell or the specific mechanisms responsible for the transduction of these cell surface signals. Such flexibility may underlie the means by which a particular neuron can differentially regulate the synthesis of colocalized neurotransmitters.

\section{References}

Beaumont, A., K. M. Metters, J. Rossier, and J. Hughes (1985) Identification of a proenkephalin precursor in striatal tissue. J. Neurochem. 44: 934-940.

Bennett, H. P. J., C. A. Browne, and S. Solomon (1982) Characterization of eight forms of corticotropin-like intermediate lobe peptide from the rat intermediate pituitary. J. Biol. Chem. 257: 10096-10102.

Elazar, Z., E. Motles, Y. Ely, and Y. R. Simanto (1979) Acute tolerance to the excitatory effect of enkephalin microinjections into hippocampus. Life Sci. 24: 541-548.

Gall, C., N. Brecha, K.-J. Chang, and H. J. Karten (1981a) Localization of increased hippocampal leucine enkephalin-like immunoreactivity following hilar lesions in the adult rat. Soc. Neurosci. Abstr. 7: 94.

Gall, C., N. Brecha, H. J. Karten, and K.-J. Chang (1981b) Localization of enkephalin-like immunoreactivity to identified axonal and neuronal populations of the rat hippocampus. J. Comp. Neurol. 198: 335-350.

Gall, C. M., R. M. Pico, and J. C. Lauterborn (1986) Focal hippocampal lesions induce seizures and long-lasting changes in mossy fiber enkephalin and CCK immunoreactivity. Peptides (in press).

Hong, J. S., P. L. Wood, J. C. Gillin, H. Y. T. Yang, and E. Costa (1980) Changes of hippocampal Met-enkephalin content after recurrent motor seizures. Nature 285: 231-232.

Hong, J. S., T. Kanamatsu, J. F. McGinty, J. Obie, R. S. Dyre, and C. L. Mitchell (1985a) Amygdaloid kindling increases enkephalin-like immunoreactivity but decreases dynorphin A-like immunoreactivity in rat hippocampus. Fed. Proc. 44: 425.

Hong, J. S., K. Yoshikawa, T. Kanamatsu, J. F. McGinty, C. L. Mitchell, and S. L. Sabol (1985b) Repeated electroconvulsive shock alters biosynthesis of enkephalin and concentration of dynorphin in rat brain. Neuropeptides 5: 557-560.

Kilpatrick, D. L., T. Tanaguchi, B. N. Jones, A. S. Stern, J. E. Shively, J. Hullihan, S. Kimura, S. Stein, and S. Udenfriend (1981) A highly potent 3200 dalton adrenal opioid peptide that contains both a [Met]and [Leu]-enkephalin sequence. Proc. Natl. Acad. Sci. USA 78: $3265-$ 3268.

LaGamma, E. F., J. E. Adler, and I. B. Black (1984) Impulse activity differentially regulates [Leu] enkephalin and catecholamine characters in the adrenal medulla. Science 224: 1102-1104.

LaGamma, E. F., J. D. White, J. E. Adler, J. E. Krause, J. F. McKelvy, and I. B. Black (1985) Depolarization regulates adrenal preproenkephalin mRNA. Proc. Natl. Acad. Sci. USA 82: 8252-8255.

Lowry, O. H., N. J. Rosebrough, A. L. Farr, and R. J. Randall (1951) Protein measurement with the Folin phenol reagent. J. Biol. Chem. 193: 265-275.

Malamud, N. (1966) The epileptogenic focus in temporal lobe epilepsy from a pathological standpoint. Arch. Neurol. 14: 190-195.

McGinty, J. F., S. J. Henriksen, A. Goldstein, L. Terenius, and F. E. Bloom (1983) Dynorphin is contained within hippocampal mossy fibers: Immunohistochemical alterations after kainic acid administration and colchicine-induced cytotoxicity. Proc. Natl. Acad. Sci. USA 80: 589-593.

McKelvey, J. F., J. E. Krause, and J. D. White (1983) Methods for the study of the biosynthesis of neuroendocrine peptides in vivo and in vitro. Methods Enzymol. 103: 511-524.

Racine, R. (1972) Modulation of seizure activity by electrical stimulation: II. Motor seizure. Electroencephalogr. Clin. Neurophysiol. 32: 281-294.

Schwartzkroin, P., and D. A. Prince (1978) Cellular and field potential properties of epileptogenic hippocampal slices. Brain Res. 147: 117130.

Weber, E., F. S. Esch, P. Boehlen, S. Paterson, A. D. Corbett, A. T. McKnight, H. W. Kosterlitz, J. D. Barchas, and C. J. Evans (1983) Metorphamide: Isolation, structure and biologic activity of an amidated octapeptide from bovine brain. Proc. Natl. Acad. Sci. USA 80 : 7362-7366.

White, J. D., and J. F. McKelvy (1986) Enkephalin biosynthesis and processing during lactation. Neuroendocrinology 43: 377-382.

White, J. D., J. E. Krause, and J. F. McKelvy (1984) In vivo biosynthesis and transport of oxytocin, vasopressin and neurophysins to posterior pituitary and nucleus of the solitary tract. J. Neurosci. 4: 1262-1270.

White, J. D., C. M. Gall, and J. F. McKelvey (1986a) Proenkephalin in processed in a projection-specific manner in the rat central nervous system. Proc. Natl. Acad. Sci. USA 83: 7099-7103. 
White, J. D., K. D. Stewart, and J. F. McKelvy (1986b) Measurement of neuroendocrine mRNA in discrete brain regions. Methods Enzymol. 124: 548-560.

Yoshikawa, K., C. Williams, and S. L. Sabol (1984) Rat brain pre- proenkephalin mRNA. J. Biol. Chem. 259: 14301-14308.

Yoshikawa, K., J. S. Hong, and S. L. Sabol (1985) Electroconvulsive shock increases preproenkephalin messenger RNA abundance in rat hypothalamus. Proc. Natl. Acad. Sci. USA 82: 589-593. 